\title{
The fostering factors in the occurrence of rural small industries and enterprises in the Northeast of Thailand
}

\author{
Suranart Khamanarong \\ (Faculty of Humanities and Social Sciences, Khon Kaen University, Khon Kaen 40002, Thailand)
}

\begin{abstract}
The rural small industry and enterprise have a close relation with the regional development. Although they generated job and income, the number of them increased quite low in the area. The previous study focused on the financial support on the hypothesis of lack of capital. Many agencies had provided the variety fund, but the number of them increased not so high. In the study, the author focuses in the management background on the basis that capital is the important issue but not the major factor. The management background should have a role. The author studies 370 small industries and enterprises of every type in the region. The study found that the major three issues that are the fostering factors in the occurrence of them are management background, capital, and creative thinking. Management background of entrepreneur that relate directly to their experience is a major factor rather than capital. The regression coefficient show significantly. The study can bring new strategy to develop them in the future.
\end{abstract}

Key words: rural small industry and enterprise; occurrence of business; regional development

\section{Introduction}

In the new era nobody deny that industry and trade is an important activity in economy. Although it changed under globalization, it expanded not only to trading activity but also the potential embarked of the involved agencies. Information flew very fast with modern technologies and led almost every sector developed as fast as it could. This change was also due to the involved agencies, particularly the producers, sellers, and the promotion authority in the new adaptation.

Industrial sector in Thailand was also led by these environments and became dynamic by the activity of both government and private agencies. The revival of business is the interesting theme that shows the clearer view of change in many parts of the world including Thailand. The newly association of countries in Asia became enhanced with the force of trade. This force came from the need to survive under the regulation of World Trade Organization. Therefore the dynamism of enterprises and production were interested.

In the study, we attempted to broad the macro view of whole Thailand in the international trade. Then we tried to focus on the small firms as the second part of study. The reason of this discussion is the important of its real sector at local level of the country. Rural industry was also the point, including with small enterprises. They are the major actors in the new view of trading firms. The occurrence of theme is very interesting. It will be used as a model of pushing rural industry and enterprise in other countries as well. This part we do present some fostering factors that relate directly to their occurrence. So, it will be a model if other countries interest in.

Suranart Khamanarong, Ph.D., associate professor, Industrial and Enterprising Administration Program, Faculty of Humanities and Social Sciences, Khon Kaen University; research field: industrial and enterprising administration. 


\section{Thailand's industrial profile}

Thailand's economy passed boom and bust for many times in the last twenty years. During 1987-1992 the economy rose up when every part of production bound for export. The production firms concentrated in quality development and could export their products to almost every part of the world. Thailand was called the newly industrializing country at that time after the economic structure changed from agricultural-base to industrial-base. Unfortunately, it went bust in 1997 when economic crisis occurred in many parts of Asia because of the financial tension. The currency attack was a major problem when economic growth was higher than the real currency exchange rate. It was due to the over foreign debt crisis when the government decided to use floating currency rate. The production firm faced very big problem of high material cost at that time when they had to import them. The problem spread to the whole system. The economy was almost the bankruptcy businessmen at that moment. Every production firms tried to work hard and then they found success. At present, the producers and entrepreneurs try to stand up in the world competition again. It seems to be a difficult process, but they succeed.

The export volume declined down for a short term after crisis, the boosting activities were applied to cheer up domestic goods in distributing international market. In 2001-2004 export of the whole country expanded to over import and showed some potential to cope economy. The electronic goods acted as the major group of export that expanded at a high percentage compared with the previous period. It is a meaningful condition of domestic production to show the international competitiveness which is full of strict barrier.

The statistic of economic structure of export showed that the industrial goods were the major group which had a value of more than $70 \%$ of total export. The agricultural commodities and agro-industrial products were the second.

In 2007 the export volume expanded to 151.1 thousand million US dollars, the growth rate was $18.1 \%$. While import volume was 139.1 thousand million US dollars and the growth rate was $9.6 \%$. It was quite the same rate in the last five years. The export volume expanded almost every year. It shows that the population of 63.04 million people worked harder year by year to stand up in the world market.

The export of Thai product fall into four major markets: The United State of America, ASEAN countries, Europe Union, and Japan. However, export to new market such as African Countries, Middle East Countries, Russia, China, and India tends to increase the value quite meaningfully.

\section{The export of industrial goods}

The export product of Thailand fell into many categories. It depended on the market in each country. The export products to USA mostly were garment, electronic compliance, canned sea food, and electronic circuit.

These categories were the same categories as the export to Japan and EU, but some were different. The major categories of export to Japan mostly were the electronic appliance, car and accessories, and sea food.

Despite of 4 major markets of Thai export product, the effort of producers and government agencies in expanding the market to the new marketing countries become effective. These new market include China, India, Africa and Russia.

China is a big market of Thai product since China had the dealing with World Trade Organization. The export to China fell into the material goods and electronic goods such as computer and appliance, steel, chemical product, plastic and rubber. However, the potential products that have good future in exporting to China were steel, fresh fruit, car and component. The value of export to China of Thai product tends to increase every year. 
Not only China plays an important role to be a new market of Thai product, but also the other new countries. Many countries in the big part of the world such as China, India, and Russia were also related the connection in trading activities at all. The export to India was like an exchange goods and service.

Although India imported the material goods from Thailand, the finished goods had a good volume. While Indian computer Industry boomed, the export of Computer and component from Thailand was also boom. Africa was also the good market for Thai product. The close relation and the same need of product as Thai people was a valuable push to the domestic producer to export. The firms which had never exported began to have new chance. The export of common goods for the basic need of people in that region made the export volume expand. The volume of export to Africa expanded in a good rate. The rice product was the first rank of highest category, the car and accessories came the second, and machine and plastic product were the third.

\section{Rural industry in the international market}

The export discussed above is the major product in the globalizing world. Although the product that export to the big countries lied on the item of high-technological product, the product with medium technology and handicraft could play a good role in small countries and showed a good potential to develop very well.

Rural industry had a long history and distributed to supply the need of people in the local area. Mostly, these products supplied the people in the nearby area, only some products that had higher potential and source of fund could distribute to the entire country.

Rural industry was boomed since some kinds of product could export and some firms were developed to be big firms in a few years after the beginning stage. After the economic crisis and the central government converted their policy to promote small and medium enterprises to maintain the entire economy, the local production was one concentrated point. Some countries had experience in promoting these producer groups to hold and drive economy at the bottom line. Thailand also used this strategy in maintaining the bottom economy. In practice, the promotion at that time did not focus directly to the real production at base line. Later the policy makers changed their theme from the promotion of whole small enterprises to the local enterprises. This way of development ran on the same direction of academicians that tried to point out long time ago. However, this policy could account to be a first step to change the interesting point from the big firms to the small firms.

Although the production at the beginning stage made a quantity of products and producers, the second stage was quite concentrate on quality. The encouragement of producers to the globalizing world was quite meaningful. Many products could export with good quality. This export potential could remark the good management that developed by the producers themselves.

These products were promoted to export in many ways. The effective activities were the trade show in many countries around the world. The trade show built up the connection between local producers and distributors abroad. The volume of export was pushed up to pass though this channel.

The international meeting was another way that could give the introduction of these products very well. The order came after the official meeting of trade delegation from the member countries. This way made some products distribute in the international market.

\section{New product of rural industry}

Service industry became bright when the world concentrated in the health and beauty. The consumers 
expected to have a good health and tried to find service and product around the world. Thailand was a good choice for the consumers, particularly consumers from America Europe and Asia. Service industry such as health and beauty in Thailand could induce customer with a good satisfaction.

This kind of product was responsive to the increasing world market in health and beauty awareness. The customer can learn about the natural way of supporting quality of life by utilizing Thai herbs. The potential of the health and beauty service in Thailand on par with the international standard was also the key.

Thai service is an outstanding product by its perfect with all combination of climate, food and herbs. Moreover, a traditional Thai massages, health and beauty services, natural and herbal methods were the catalyst. This full course service was a charm to pull customer in the recent year and tends to be an inducing product in the future if the entrepreneur realize in customer's need.

This kind of service product that welcome customer seems like they open the door for those who care for their health and beauty from all around the world. Most of the service centers that welcome foreigner were trained to treat the customer with a full course.

However, the service product depends on the satisfaction of customers. If the product is good and maintain the standard as long as they can, it will be a new export product that not only abroad but also domestic at different places.

Another new product that boosted Thailand export growth is a fashioned garment. The fashion industry in Thailand grew with a rapid rate during the last ten years. Because its scrupulous work and modern design made the product become famous in the world. Although the competitor offered lower price product, the higher quality and its charm in modernize could attract customer at better condition.

The export of these products pulled the distributors around the world came to buy and order at the production place. The E-commerce channel was a best way to contact with and introduce new product to customers. The promoted activities of government to boom Thailand as a fashioned city made this kind of industry interested. The fashion fair was organized around the world every month by the coordination of government agency and private firms. The good promotion and good product was a good condition to drive it as a new product in the world market for a long time.

The above products will be the new industry that spread entire country especially the regional area. The service industry and fashioned industry were produced in many parts of the country. Although it is not rural industry in the sense of rural production of peasant, it is like the regional production which was not produced in the central or capital region.

\section{The occurrence of rural small industry and enterprise}

The rural production is a base line to share the benefit when the country goes to the world. If the country launch to distribute their products worldwide and the rural sector which produce the bottom support could not benefit, the wealth or the share of economy will fall to the top triangle of society that quite harmful. Because of the bottom production played a role as a base structure of economy, so its manufacturing is quite important.

The study was done during 2007 by collecting the data in the northeast of Thailand. The number of 370 cases was collected. The objective of study was to find out the influence factors that force entrepreneur start their rural industries and enterprises in the area. We studied production, service and trade. The dependent variables were attention, location, capital, creative thinking, management background, technology and knowledge. The 
assumption was the good attention, good location of workplace, good knowledge and some sufficient factors could create industry and enterprise in the area. After we test by using regression method, we found that the overall variable test is quite significance $\left(\mathrm{R}^{2}=0.338\right.$ at $95 \%$ confidence). When we test each variable, the major three variables showed significance that are management background $\left(R^{2}=0.286\right)$, capital $\left(R^{2}=0.167\right)$ and creative thinking $\left(\mathrm{R}^{2}=0.153\right)$ respectively. This statistic test showed that good management background including with sufficient capital and creative thinking were related directly to the starting of the rural small industry and enterprise.

It shows that the previous study which believe in the important of capital and pay attention to the provision of sufficient capital may be not so effective. Although the sufficient capital may be the important issue in investment, it is not the real factor to boost rural small industry and enterprise in the regional area. It is like a supportive issue when entrepreneur decide to start their businesses. The very important issue in this case is the management background. That means the entrepreneur with management background decide easier to start business than only money for their investment. The management background includes the experience and skill in management. The management background came from variety source. The entrepreneur of some firms had their experience in other firms before starting their own firm, and some entrepreneurs had their skill in management of other related business before doing direct production.

\section{Fostering factors to policy implication}

It may be strange if we say that the study found the different issue that is not the same issue of other study. It is not so strange when the study showed the new factors that are possible to design for policy when we want to promote regional development. We can use these fostering factors to be the base line of provision. The government agency and local business promotion agency may use these factors to set up their strategy to boost new rural small industry and enterprise in their area. They may create training course in management or promote the businessmen who have experience in doing the new production or enterprise in the remote area. This strategy is not only creating the new firms to increase the number of rural industry and enterprise but also boosting people. People who have saving should learn enough management before starting their own businesses in rural industry and enterprise. The entrepreneur may fell certain when they have management skill enough for their new firm. This skill will be the push factor or fostering factor to push them start running business. So, the fostering factors on the occurrence of rural small industry and enterprise are the major issue which may be the factors of policy implication if we realize them.

\section{Conclusion}

Thailand's rural industry and enterprise played a role in the distribution of their products around the world at a good image. While the country's total export increases every year, this number also includes the product of rural industry and enterprise. Particularly, the new market such as China, India, Russia, and Africa show some good signals to the rural production. The export volume to the new market could increase significantly. Furthermore, the country's new products could induce consumer so well. Moreover, the rural product shows a good chance to develop for both domestic and international market at a satisfactory level. It is reasonable if rural industry and enterprise which mostly the small firms are promoted to boost regional development.

The strategy to boost these firms is still waiting for government officers and local business organization to 
promote creating. The policy implication may convert to boost management background or management skill at the first point rather than boosting the investment fund. The investment fund may be important for business, but it is not the first factor to push entrepreneur design at the beginning. It will be the second factor to fulfill the readiness of starting, but the first factor should be fulfilled before thinking further.

It may be the new strategy of economic and regional development to promote rural small industry and enterprise by pushing or providing these factors to fulfill the conditions for the occurrence of them.

\section{References:}

Bank of Thailand. (2008). Annual Report 2007. Bangkok: Bank of Thailand.

Department of Export Promotion. (2008). Thailand's international trade. Bangkok: Department of Export Promotion, Ministry of Commerce.

Department of Industrial Promotion. (2008). Industrial production. Bangkok: Department of Industrial Production, Ministry of Industry.

Information Centre. (2008). Export statistics. Bangkok: Information Centre, Ministry of Commerce.

Retrieved July 25, 2008, from http://www.depthai.go.th.

Retrieved July 25, 2008, from http://www.dip.go.th.

Retrieved July 25, 2008, from http://www.bot.or.th.

(Edited by Emily and Ann)

\section{(continued from Page 13)}

industrial cluster development, the local government and the leading enterprises are the major part of public service platform constructing of industrial cluster, particularly, the guidance and promoting of local government plays important roles. The constructing of public service platform of industrial cluster, it involves technological innovation (function of Productivity Center and R \& D Center), product quality inspection (function of Inspection and Test Center), enterprises financing (function of Guarantee Agency), product sales (function of Product Center and Professional Market), human resource development (function of Training Institutions) and industry self-government service (function of Industry Association), etc.

\section{References:}

Michael E. Porter. (1998). Clusters and the new economics of competitiveness. Harvard Business Review, 76(6), 77-90.

Michael E. Porter. (1998). On competition. Boston: Harvard Business School Press.

Regional Economics Researching Center of Wuhan University. (2009). Annual Report of the Hubei Province Key-developing Industrial Clusters, 2008.

(Edited by Annie and Ann) 